\title{
Exploration of Understorey Vegetation's Beauty: Supporting Tourism Potential of Bukit Siguntang, Palembang
}

\author{
Lia Auliandari ${ }^{1}$, Delfy Lensari ${ }^{2}$, Erni Angraini ${ }^{3}$ \\ 1,3Study Program of Biology Education, Faculty of Teacher Training and Education, University of Muhammadiyah \\ Palembang, Indonesia \\ ${ }^{2}$ Study Program of Forestry, Faculty of Agriculture, University of Muhammadiyah Palembang, Indonesia
}

\begin{abstract}
Bukit Siguntang Forest, an urban forest on a hill filled by trees that are believed to be a tomb complex of Malay kings. As an ecosystem, Bukit Siguntang Forest also consists of various understorey. Because of the tourist location, the understorey of Bukit Siguntang Forest tends to be easier to encounter cleaning which is considered as weed and disturbs beauty. The study purpose was to explore the aesthetic potential of the understorey vegetation of Bukit Siguntang Forest. The study method used vegetation analysis with the plot measuring $2 \mathrm{~m} \times 2 \mathrm{~m}$, which was followed by species identification. The results showed that the understorey identified as dominating species with aesthetic potential were Asystasia gangetica, Bidens pilosa, Borreria laevis, Drymaria cordata, and Mimosa pudica. The understorey which is included in herbs and shrubs had beautiful flowers, unique leaf shapes, and attractive colors. These plants provide the beauty of their parts so that they can be applied to form a flower bed, green coverage and refreshing scenery. However, the growth of understorey also needs to be controlled. That is because understorey can grow rapidly, so that will be growing too densely and messy planting mode.
\end{abstract}

Keywords: aesthetic function, Bukit Siguntang, tourism, understorey vegetation.

\section{INTRODUCTION}

Urban forest is the maintained or built forest in urban area that is consisted of woody vegetation, which has two main functions, namely intrinsic function (as an ecological function) and extrinsic function [1-4]. Therefore, Government of Palembang City through Regional Regulation (Peraturan Daerah) No. 15 of 2012 concerning the Regional Spatial Plan (Rencana Tata Ruang Wilayah) of Palembang City in 20122032 determined certain areas as urban forests. One of the urban forest areas is Bukit Siguntang Forest [5].

Bukit Siguntang Forest, although as an urban forest, is not only consisted of large trees (woody vegetation). Bukit Siguntang Forest also has the diverse understorey vegetation, which forms a complex ecosystem. Large trees and understorey are biotic components in ecosystems that have their respective roles [6] as key elements of Bukit Siguntang Forest [7]. Large trees with their canopy give the effect to microclimate through photosynthesis and evapotranspiration processes so as to reduce the heat island effect, and affect the air quality and noise levels $[7,8,9]$. While the

\footnotetext{
${ }^{*}$ Correspondence address: Lia Auliandari

Email : lia_auliandari@um-palembang.ac.id

Address : Study Program of Biology Education, University of Muhammadiyah Palembang. Jend. A. Yani Street 13 Ulu Palembang, South Sumatra 30263
}

understorey vegetation occupies the position as ground cover or forest floor. The understorey plays the role in influencing underground processes such as decomposition, nutrient flow, and buildup of soil nutrients [10]. In addition, the understorey also plays a role in reducing the rate of surface runoff, thus reducing the potential for erosion [11,12].

The main extrinsic function of Bukit Siguntang Forest is a social and cultural function. This is because Bukit Siguntang Forest is one of the tourist destinations in Palembang City which contains a tomb complex of Malay kings. Because of this tourism location, the understorey vegetation of Bukit Siguntang Forest tends to be easier to encounter regular cleaning/weeding which is considered as a weed and disturbs the beauty. Besides being the main function in ecosystem, the understorey along with woody vegetation (trees) forms forest floors, walls and canopies which are architectural characteristics that provide an aesthetic function [13], thus provide the source of aesthetic inspiration and the various forms of recreation that support the health [14]. The understorey and trees in Bukit Siguntang Forest will help reduce the stress suffered by urban people due to the harshness of city life through coolness and natural beauty [3].

The understorey plants that can provide the aesthetic value, e.g. beautifying, improving the urban environment and enriching the landscape, are plants that include in herbs and shrubs. Herbs 
and shrubs have been widely applied in the form of botanical garden, flower bed and greening of gardens since a long time ago [15]. Therefore, this study aimed to explore the aesthetic potential of the understorey vegetation (herbs and shrubs) in Bukit Siguntang Forest.

\section{RESEARCH METHODS Study Area}

Based on Regional Regulation of Palembang City No. 15 of 2012 concerning the Regional Spatial Plan of Palembang City in 2012-2032, Bukit Siguntangarea is an area of 7 ha which is planned to be one of urban forests in Palembang City [5]. Bukit Siguntang area is a hill filled with parks and large trees and as the highest landscape in Palembang with a height about 26 $\mathrm{m}$ above sea level (Fig. 1). This location is under the responsibility of Department of Culture and Tourism of South Sumatra Province.

Bukit Siguntang is one of the tourism destinations in Palembang City which has the high historical value. Bukit Siguntang, by some Malay people in Sumatra and the Malay Peninsula, was considered sacred, because it was the origin of the Malays. Bukit Siguntang was also considered to be the location of Parameswara, the King of Palembang who brought down kings on Malay Peninsula. During the Srivijaya period, Bukit Siguntang played an important role as a place of worship and pilgrimage for Buddhists. Another role played by Bukit Siguntang was the location of people meetings in Srivijaya. With these three important roles, Bukit Siguntang was considered the heart of Srivijaya Kingdom. During the Islamic period Bukit Siguntang was considered the origin place of Malay kings in the Archipelago. The other role of Bukit Siguntang in the Islamic period was as a place for people to commit spite if there were disputes among residents [16].

This time, Bukit Siguntang as the highest point in Palembang City is believed to be a tomb complex. The tomb complex is located on the highest ground. There are seven Srivijayan figures' tombs linked by locals to the figures of Malay-Srivijayan royalties and heroes. They were King Sigentar Alam, Prince Raja Batu Api, Princess Kembang Dadar, Princess Rambut Selako, Commander Tuan Junjungan, Commander Bagus Kuning, and Commander Bagus Karang [17].

\section{Data Collection and Analysis}

This study was the qualitative descriptive research conducted in September 2018. The floristic exploration of understorey vegetation in Bukit Siguntang Forest was carried out troughh the quadrant method with plots of $2 \mathrm{~m} \times 2 \mathrm{~m}$. The plots that used in the study aimed to inventory the understorey vegetation in the form of herbaceous and shrub plants. For unknown understorey encountered during fieldwork, notes of understorey's features were carried out, and then documented in the form of photos. Based on notes and photos, the identification was carried out using scientific articles and classification books related to understorey (herbs and shrubs).

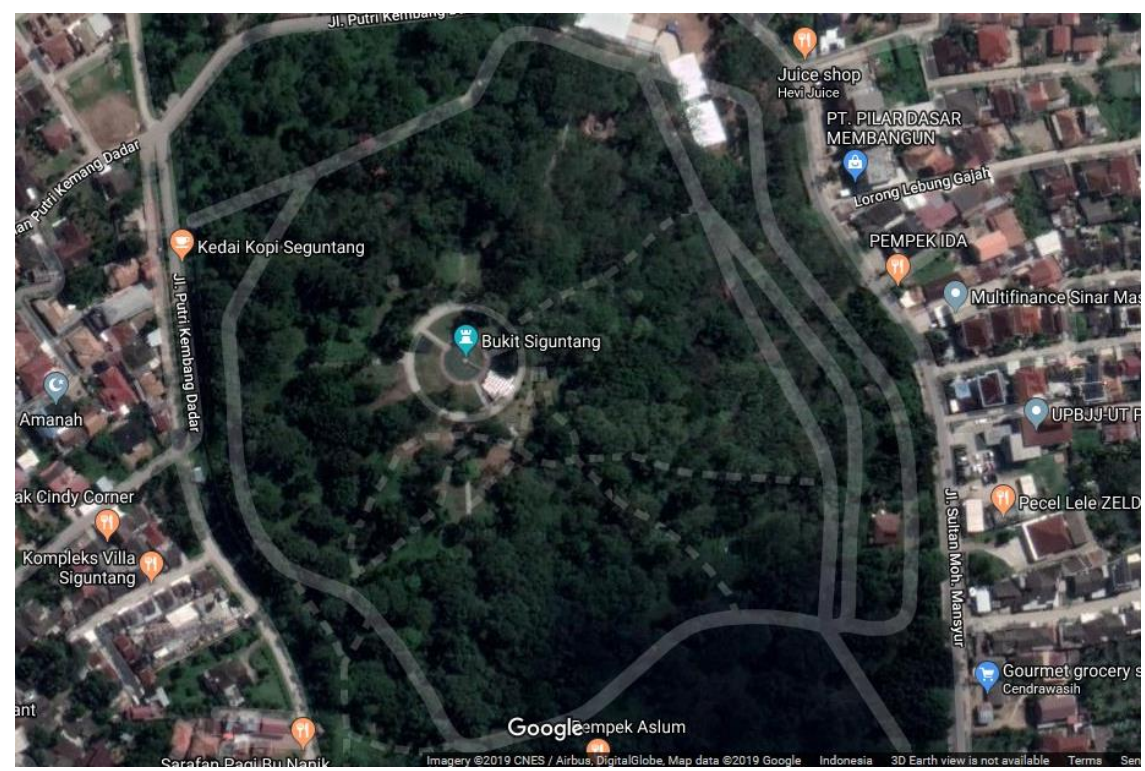

Figure 1. The Study Site: Bukit Siguntang. Scale $1: 2500$.

Source: Google Map, 2019. 
During the data collection process, the species richness of understrorey vegetation was counted, so that the number of individual species was known. Species richness was the count of species [18]. The species with the most individuals was considered as dominant species that followed by codominant species. Therefore, the data analysis to answer the aim of study was qualitatively by using observational notes, photos, scientific articles, and reference books, so that the aesthetic potential of the dominant and codominant understorey can be known. The aesthetic potential of the dominant and codominant understoreiescan be explored through their interesting parts, such as beautiful flower, unique leaf shape and attractive color.

\section{RESULT AND DISCUSSION}

\section{Understorey in Bukit Siguntang Urban Forest}

Bukit Siguntang with its high historical value is a lush green hill. The shady trees will welcome visitors for the first time when they enter the hill. Therefore, the Government of Palembang City set Bukit Siguntang as one of the urban forests. Although as urban forest, Bukit Siguntang also has other vegetation, namely the understorey vegetation. The understorey has ecological functions (intrinsic function) as the main function in ecosystem. Its role in ecosystems affects underground processes such as decomposition, nutrient flow, buildup of soil nutrients [10]. The understorey also plays the role in reducing the rate of surface run off, thus reducing the potential for erosion [11].

In order not to reduce the ecological functions of the understorey, the beauty of the understorey also needs to be known to provide added value. It is the aesthetic value of understorey (one of the extrinsic functions). The understorey can also provide the beauty through its parts. The understorey and trees in Bukit Siguntang provide the beautiful and green view in the middle of Palembang City which is filled by buildings and markets. The identified understoreisas dominant and codominant species that considered to have aesthetic potential through their interesting parts were explained as follows.

\section{Asystasia gangetica (Chinese Violet)}

Asystasia gangetica is perennial herbs, erect, decumbent, or clambering; 1-3 $\mathrm{m}$ in length. Stems quadrangular. Leaves opposite; blades simple, with numerous linear cystoliths on the upper surface, the secondary veins conspicuous; stipules absent. Flowers are bisexual, zygomorphic, arranged in spikes on axillary branches. Calyx is green, 5-7 mm long, the sepals lanceolate; corolla asymmetrically funnel-shaped, light yellow or pale violet, $2.3-5 \mathrm{~cm}$ long, with glandular hairs on the outer surface; stamens and pistil inserted on the floral tube. Capsules ellipsoid or club-shaped, 2-2.5 cm long, light brown when ripe, densely covered with glandular hairs; seeds 2-4 light brown, with irregular margins, lenticular [19]. The beauty of Asystasia gangetica is shown in Figure 2.

\section{Bidens pilosa (Blackjack)}

Bidens pilosa is an erect annual herb [20], widely distributed across temperate and tropical regions [21]. It is $20-150 \mathrm{~cm}$ tall (in tall plants sometimes the branches straggling), very variable, reproducing by seeds. Main root is pivotant. Its stems are square, glabrous or minutely hairy, green or with brown strips [20, 21]. Dark green, opposite leaves on stems and branches, 4-20 cm long, up to $6 \mathrm{~cm}$ wide, the lower leaves simple, ovate and serrate, the upper leaves trifoliolate or imparipinnate with 2-3 pairs of pinnae and a single terminal leaflet. Petioles are $2-5 \mathrm{~cm}$ long [20].

The inflorescence is an isolated or grouped pedunculated capitula, emerging from the leaf axil. Heads borne singly at the ends of long, slender, nearly leafless branches; narrow, discoid, the disk 4-6 $\mathrm{mm}$ wide at anthesis; ray florets, absent or 4-7 per head, white or paleyellow, 2-8 mm long, disk florets, 35-75 per head, yellow. Achenes (commonly referred to as 'seeds') linear, black or dark brown, 1-1.5 cm long, flat, 4-angled, sparsely hairy. Pappus with $2-3(-5)$ yellowish barbed awns, $1-2 \mathrm{~mm}$ long. The achenes are the dispersal units; dispersion is aided by the awns as they readily attach to animal skin, machinery and clothing. B. pilosa is a short-day plant, the critical day length being 15 hours. The plant response to controlled photoperiod depends on the time of year. The minimum period for inducing flowering is between 10 and 14 short days. Induction could only begin with the third pair of leaves fully expanded [20]. B. pilosa prefers full sun and moderately dry soil. However, it can grow in arid and barren land from low to high elevations [21]. B. pilosa is shown in Figure 3. 


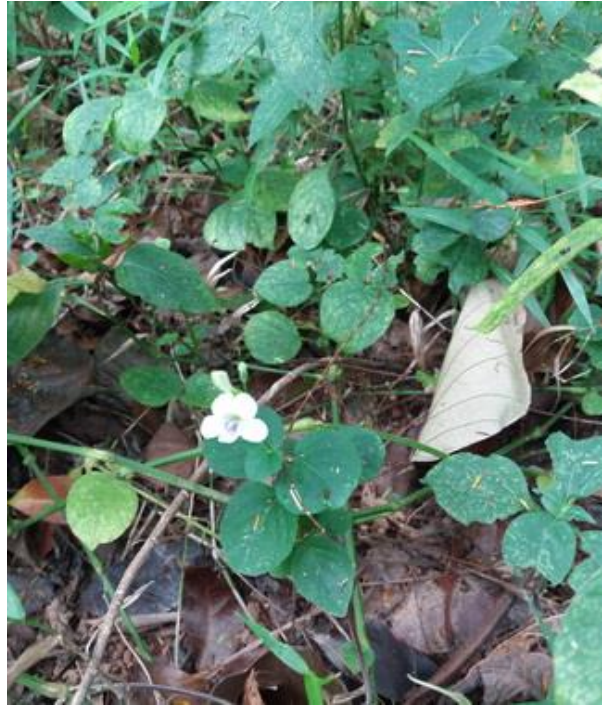

(Personal Documentation, 2018)

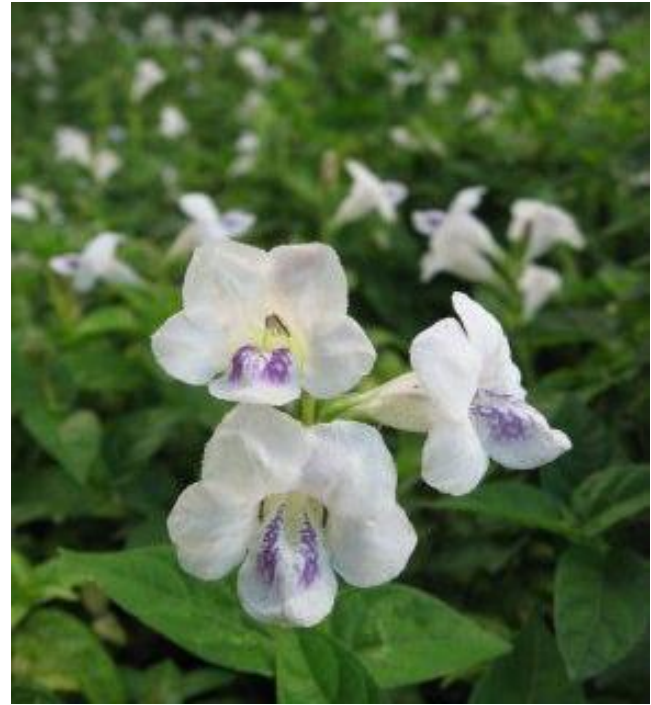

[22]

Figure 2. Asystasia gangetica with its beautiful flower in the midst of greenery

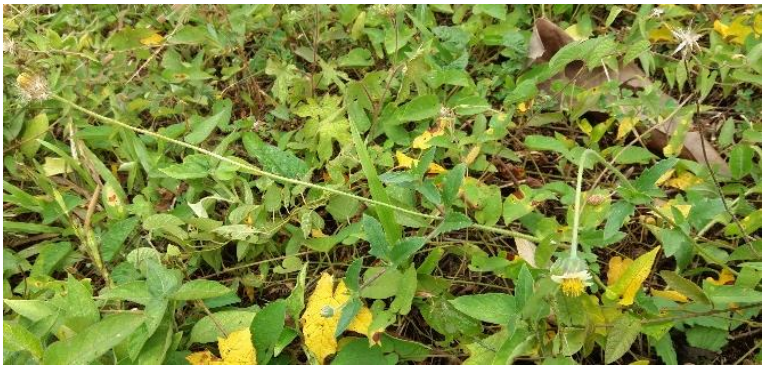

(Personal Documentation, 2018)

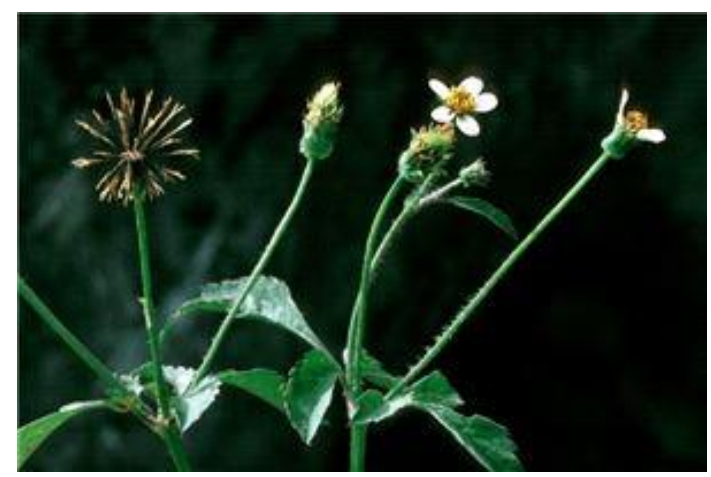

[20]

Figure 3. Bidens pilosawith straggling branches

\section{Borreria laevis}

Borreria laevis is erect or scrambling annual herb 0.3-1.2 $\mathrm{m}$ tall; stems with slight ribs, glabrous or with lines of very short sparse hairs. Leaf-blades narrowly elliptic or elliptic-lanceolate to ovate, $0.8-5.5 \mathrm{~cm}$ long, $0.3-2.5 \mathrm{~cm}$ wide, acute at the apex, cuneate at the base into the stipulesheath, the very narrow leaf-base resembling a short petiole $\pm 2 \mathrm{~mm}$ long, entirely glabrous save for very short hairs at and near margins above giving a slightly scabrid feel; stipules drying a rather bright reddish brown; bases slightly pubescent, 2-3 $\mathrm{mm}$ long, with 5-7 fine fimbriae $2.5 \mathrm{~mm}$ long, or at inflorescence-bearing nodes \pm $100.5 \mathrm{~mm}$ long. Flowers in terminal and axillary many-flowered sessile clusters; stipule-derived bracteoles with fimbriae $3 \mathrm{~mm}$. long. Calyx-tube narrowly obconic, $2-2.5 \mathrm{~mm}$. long, $0.8 \mathrm{~mm}$ wide, densely hairy above; limb obsolete; lobes triangular, $0.6 \mathrm{~mm}$ long, ciliate, separated by a fringe. Corolla white or lobes tipped with pink; tube $1.2 \mathrm{~mm}$ long; lobes lanceolate, $1.3 \mathrm{~mm}$ long, $0.6 \mathrm{~mm}$ wide, slightly hairy at the apex outside. Stamens with filaments exserted 1-1.2 mm Style exserted $1.3 \mathrm{~mm}$; stigma $0.5 \mathrm{~mm}$ wide. Capsule ellipsoid or obovoid-fusiform, 2.5-4 mm long, $1.8 \mathrm{~mm}$ wide, $1 \mathrm{~mm}$ thick, hairy above, the valves completely falling, each $2.2 \mathrm{~mm}$ long, $1.8 \mathrm{~mm}$ wide, bifid at the apex, crowned by the calyxlobes. Seeds are chestnut-brown, oblongellipsoid, $1.5-2 \mathrm{~mm}$ long, $0.7-0.8 \mathrm{~mm}$ wide, 0.5 $\mathrm{mm}$ thick, divided into transverse areas by anastomosing transverse grooves, while the actual areas reticulate [23]. The beauty of Borreria laevis is shown in Figure 4. 


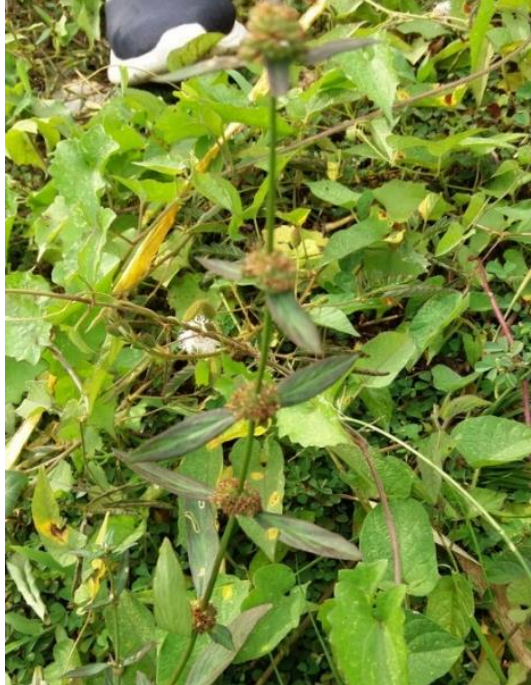

(Personal Documentation, 2018)

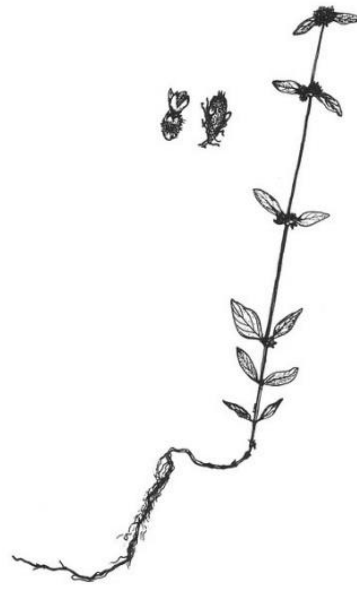

[24]

Figure 4. Borreria laevis with its unique leaf shape and color

\section{Drymaria cordata (Tropical Chickweed)}

Drymaria cordata is a weak prostrate or creeping annual, or less commonly perennial, herb up to $50 \mathrm{~cm}$ across or tall, usually with a mass of extensively branched, trailing stems which may root at the nodes. Roots are fibrous, shallow, mainly from the base of the stem but also from the lower nodes where the soil is moist. Stems are weak, trailing or ascending, usually extensively branched to form a dense mat in the centre of the plant, smooth and slender, sometimes hairy, with swollen nodes. Leaves in opposite pairs on slender 3-10 mm long petioles, round to heart-shaped or oval with rounded bases, smooth margins and rounded or bluntly pointed tips, 5-25 $\mathrm{mm}$ long and wide, hairless, weakly three-nerved, and paler below. Very short stipules persist at the bases of the petioles [25].

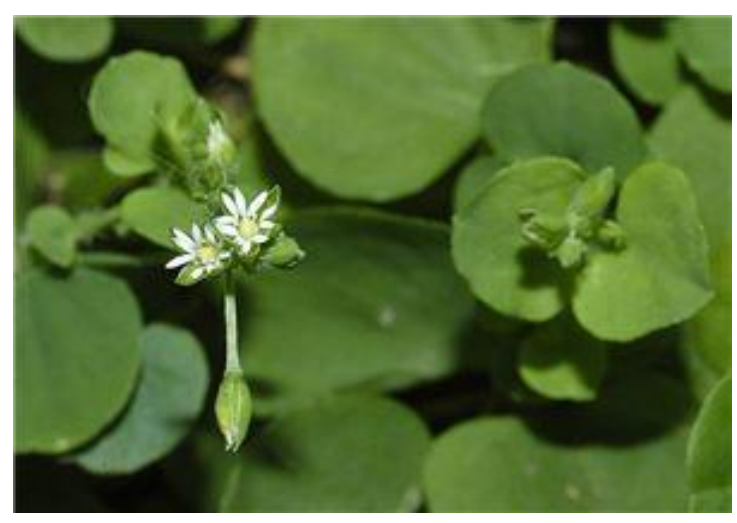

[24]
Drymaria cordata's flowers are in small repeatedly forked terminal or axillary clusters (cymes), on slender, densely hairy, 5-15 mm long pedicels. The flowers consist of five narrow green sepals 2-4 $\mathrm{mm}$ long, five, deeply forked, white petals which are shorter than the sepals, and two or three stamens surrounding the deeply divided style. The fruit is a papery capsule $2-3 \mathrm{~mm}$ across, splitting at maturity into three parts to release the 5-10 small reddish tuberculate flattened seeds. The seedlings have epigeal germination. The hypocotyls are slender, erect, and about 5 $\mathrm{mm}$ long, the cotyledons resemble the adult leaves, and the first leaves develop in tight clusters in their axils [25]. The unique and distinctive of Drymaria cordata is shown in Figure 5 .

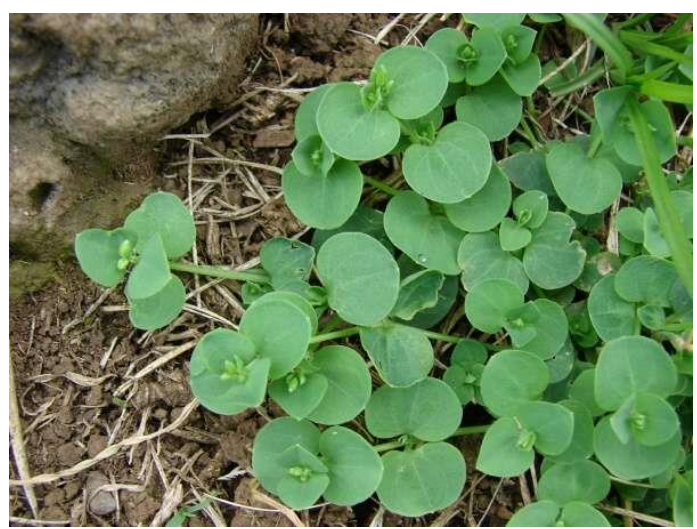

[26]

Figure 5. Drymaria cordata with small leaves and round to heart shape 


\section{Mimosa pudica (Sensitive Plant)}

Mimosa pudica is a small, prostrate or ascending, short-lived shrub. Some authors consider it a woody herb. It may reach $1 \mathrm{~m}$ in height when supported on other vegetation and more than $2 \mathrm{~m}$ in horizontal extension. Its root is cylindrical, tapering rependant, with secondary and tertiary branches, varying in length up to 2$\mathrm{cm}$ thick, surface more or less rough or longitudinally wrinkled; grayish-brown to brown, cut surface of pieces pale yellow, fracture hard, woody, bark-fibrous; odor, distinct; taste, slightly astringent. Its stem is cylindrical, up to $2.5 \mathrm{~cm}$ in diameter; sparsely prickly, covered with long, weak bristles longitudinally grooved, external surface light brown, internal surface grey, bark fibrous; easily separable from wood [27].

Its leaves are digitately compound with one or two pairs of sessile, hairy pinnae, alternate, petiolate, stipulate, linear lanceolate; leaflets 1020 pairs, $0.6-1.2-\mathrm{cm}$ long, $0.3-0.4-\mathrm{cm}$ broad, sessile, obliquely narrow or linear oblong; obliquely rounded at base, acute, nearly glabrous; yellowish green. Its flower is pink, in globose head, peduncles prickly; calyx very small; corolla pink, lobes 4, ovate oblong; stamens 4, much exerted; ovary sessile; ovules numerous. Its fruit is lomentum, simple, dry, 1-1.6-cm long, $0.4-0.5-\mathrm{cm}$ broad, with indehisced segments and persistent sutures having - two to five seeds with yellowish spreading bristle at sutures, 0.3$\mathrm{cm}$ long, glabrous, and straw colored. Its seed is compressed, oval-elliptic, brown to gray, 0-0.3$\mathrm{cm}$ long, 2.5- $\mathrm{mm}$ broad, having a central ring on each surface [28]. The unique of Mimosa pudica is shown in Figure 6.

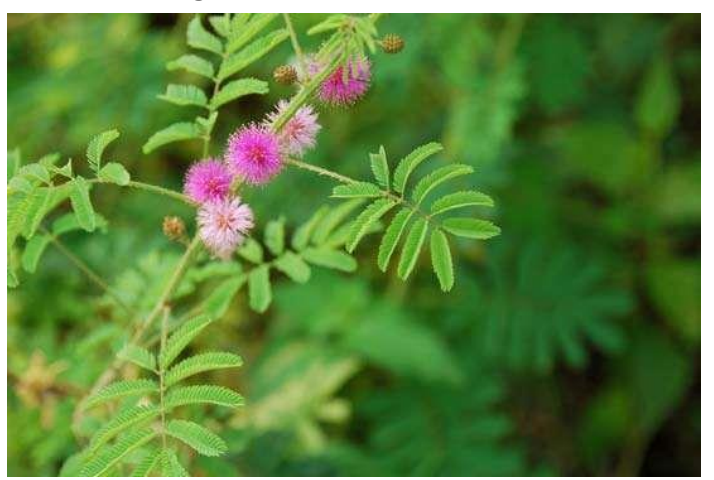

Figure 6. Mimosa pudica with attractive colored flower heads [29]

\section{Aesthetic Value of Understorey in supporting} the tourism in Bukti Siguntang

Briefly, those understrorey plants provide the aesthetic value through their interesting or unique parts are as follows:
1. Asystasia gangetica with its beautiful flower in the midst of greenery.

2. Bidens pilosa with straggling branches.

3. Borreria laevis with its unique leaf shape and color.

4. Drymaria cordata with small leaves and round to heart shape.

5. Mimosa pudica with attractive colored flower heads.

These interesting or unique parts of understory plants can be applied to form a flower bed, flower-border, green coverage and refreshing scenery (Fig. 7) [14]. But the growth of understorey also needs to be controlled. That is because understorey can grow rapidly, so that will be growing too densely and messy planting mode. Therefore, the management of this urban forest of Bukit Siguntang must pay attention for both ecological function and aesthetic function.

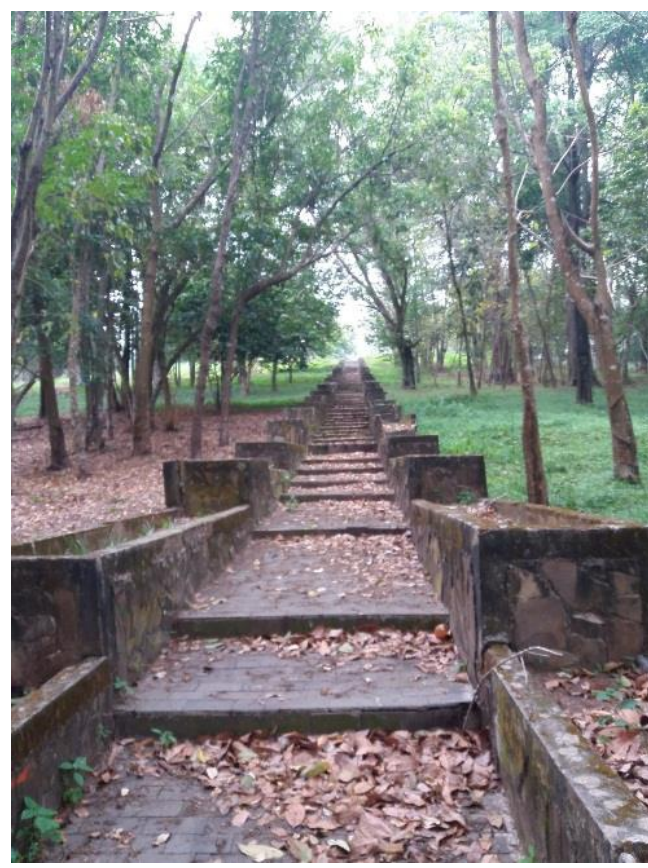

Figure 7. Asystasia gangetica on right side in this picture gives green coverage and refreshing scenery (Personal Documentation, 2018)

The focus of management is on to an urban forestry's ecological integrity, in order to reengage with landscape level processes which have important outcomes in relation to both protected area and sustainable tourism [30]. For those, beautifying Bukit Siguntang as an urban forest using understorey can consider the following [15]:

1. As landscape edging dan combining it with stone.

2. Combining it with landscape element: 
a) artistic conception and reasonable plant allocation should be considered when combining herbs with landscape architecture.

b) reasonable plant disposition and appearance should be considered when combining herbs with landscape path.

c) richly colored landscape and reasonable plant allocation should be considered when combining herbs with flowerborder.

3. It also offers attractive photo spots in the middle of Palembang City which are filled by buildings and markets.

\section{CONCLUSION}

Bukit Siguntang Forest, which is an urban forest, one of the tourist destinations in Palembang City. As an ecosystem, Bukit Siguntang Forest is also consisted of various understorey. The identified understorey vegetation as dominant and codominant species that considered to have aesthetic potential through their interesting parts were Asystasia gangetica, Bidens pilosa, Borreria laevis, Drymaria cordata, and Mimosa pudica. These interesting or unique parts of understory plants can be applied to form a flower bed, flowerborder, green coverage and refreshing scenery. However, the growth of understorey also needs to be controlled. That is because understorey can grow rapidly, so that will be growing too densely and messy planting mode.

\section{ACKNOWLEDGEMENTS}

The authors would like to thank Directorate of Research and Community Service (Direktorat Riset dan Pengabdian Masyarakat, DRPM) Directorate General of Research and Development of Ministry of Research, Technology and Higher Education (Direktorat Jendral Penguatan Riset, dan Pengembangan Kementerian Riset, Teknologi dan Pendidikan Tinggi, Kemenristekdikti) which has provided financial support for this study through Beginner Lecturer Research Grant of 2018 (Hibah Penelitian Dosen Pemula 2018). The authors also thank The Office Culture and Tourism of South Sumatra Province which has given the study permit in Bukit Siguntang, as well as to students of Biology Education Study Program and Forestry Study Program who were involved in this study.

\section{REFERENCES}

[1] Republic of Indonesia Government Regulation. 2002. No. 63 about Urban
Forest. State Secretariat. Jakarta.

[2] Department of Landscape Architecthture, Bogor Agricultural University. 2005. Pengembangan ruang terbuka hijau di kawasan perkotaan. Workshop Paper. General Directorate of Spatial Planning, Department of Public Works. Jakarta.

[3] Samsoedin, I. and E. Subiandono. 2007. Pembangunan dan pengelolaan hutan kota. In: Expose of research results: Conservation and Rehabilitation of Forest Resources. Department of Forestry. Research and Development of Forestry Office, Research Center of Forest and Nature Conservation. Padang.

[4] Waryono, T. 2008. Urgensi mewujudkan pembangunan hutan kota melalui kiat kecil menanam dewasa memanen. Kumpulan Makalah Periode 1987-2008, 1-18.

[5] Government of Palembang City. 2012. Regional Regulation No. 15 of 2012 concerning the Regional Spatial Plan of Palembang City in 2012-2032. Regional Secretary of Palembang. Palembang.

[6] Miller, Jr. G. T. and S. E. Spoolman. 2009. Living in the environment, $16^{\text {th }} \mathrm{Ed}$. Yolanda Cossio. Belmont, California, USA.

[7] Kusmana, C. 2015. Keanekaragaman hayati (biodiversitas) sebagai elemen kunci ekosistem kota hijau. Proceeding of National Seminar on Indonesian Biodiversity Community. Society for Indonesian Biodiversity (SIB) or Masyarakat Biodiversitas Indonesia (MBI). Surakarta.

[8] Dimoudi, A. and M. Nikolopoulou. 2003. Vegetation in the urban environment: microclimatic analysis and benefits. Energy and Building 35, 60-76.

[9] Rushayati, S.B. 2012. Model kota Hijau di Kabupaten Bandung Jawa Barat. Bogor Agricultural University, Bogor.

[10] Nilsson, M. C. and D. A. Wardle. 2005. Understory vegetation as a forest ecosystem driver: evidence from the Northern Swedish Boreal Forest. Front Ecological Environment 3(8), 421-428.

[11] Land for Wildlife. 2016. The value of understorey vegetation. Land for Wildlife, Australia.

[12] Zuazo, V. H. D. and C. R. R. Pleguezuelo. 2008. Soil-erosion and runoff prevention by plant covers, a review. Agronomy for Sustainable Development 28(1), 65-86.

[13] Purwanto, A. 2012. Manfaat dan guna pohon dan hutan kota. Krida Rakyat 2011. 
[14] St. Clair, C. C., M. Tremblay, F. Gainer, M. Clark, M. Murray and A. Cembrowski. 2010. Urban biodiversity: why it matters and how to protect it. The Edmonton Sustainability Papers (A Public Discussion Paper) No. 8, 2010.

[15] Zhang, L. Q., Y. J. Piao and T. D. Cho. 2013. The research on herb and its allocation form in landscape. Journal of Environmental Science International 22(2), 131-138.

[16] Nadeak, R. P. 2016. Bukit Siguntang: peranannya dalam agama Buddha pada masa Kerajaan Sriwijaya. Forum Arkeologi 29(1), 11-20.

[17] Inge, N. 2019. Menapaki tangga setapak jejak Kerajaan Sriwijaya di Bukit Siguntang Palembang. Available at: https://www.liputan6.com/regional/read/ 3990592/menapaki-tangga-setapak-jejakkerajaan-sriwijaya-di-bukit-siguntangpalembang.

[18] Tuomisto, H. 2010. A consistent terminology for quantifying species diversity? yes, it does exist. Oecologia 164, 853-860.

[19] CABI. 2018. Asystasia gangetica (Chinese Violet). Available at: https://www.cabi.org /isc/datasheet/7641.

[20] CABI. 2018. Bidens pilosa (Blackjack). Available at: https://www.cabi.org /isc/datasheet/9148.

[21] Bartolome, A. P., M. I. Villaseñor and W. C. Yang. 2013. Bidens pilosa L. (Asteraceae): botanical properties, traditional uses, phytochemistry, and pharmacology. Evidence-Based Complementary and
Alternative Medicine Article ID 340215, 151. Available at: http://dx.doi.org/10.1155/2013/340215.

[22] Asystasia gangetica. Available at: https://www.pinterest.com/pin/48392592 2430419264/

[23] JSTOR. 2018. Compilation: Borreria laevis. Available at: https://plants.jstor.org/ compilation/borreria.laevis.

[24] University of Hawaii Museum Consortium. 2006. Borreria laevis. Available at: https://www.flickr.com/photos/uhmuseu m/3403848090/in/photostream/

[25] CABI. 2018. Drymaria cordata (Tropical Chickweed. Available at: https://www.cabi. org/ISC/datasheet/20020.

[26] Wulandari, E. $2014 . \quad$ Herbarium Semarangense: Drymaria cordata (L.) Willd. Ex Schult. Jurusan Biologi FMIPA UNNES. Semarang.

[27] Kumar, N., P. Kaur, K. Das and S. Chakroborty. 2009. Mimosa pudica L., a sensitive plant. International Journal of Pharmacy and Pharmaceutical Sciences 1(2), 1-7.

[28] Ahmad, H., S. Sehgal, A. Mishra and R. Gupta. 2012. Mimosa pudica L. (Laajvanti): an overview. Pharmacognosy Reviews 6(12), 115-124.

[29] The Editors of Encyclopaedia Britannica. 2019. Sensitive plant. Available at: https://www.britannica.com/plant/sensiti ve-plant.

[30] Newsome, D., S. A. Moore and R. K. Dowling. 2012. Natural area tourism: ecology, impacts and management. Channel View Publication, Perth. 